PONTIFícIa UNIVERSIDADE CATÓlicA do RIO dE JANEIRO

\title{
A INFLUÊNCIA DO FANATISMO DO TORCEDOR NA INTENÇÃO DE COMPRA DE PRODUTOS LICENCIADOS POR TIMES DE FUTEBOL \\ Lucas Lopes Fernandes
}

Trabalho de Conclusão de Curso

ESCOLA DE NEGÓCIOS PUC-RIO

DEPARTAMENTO DE AdMINISTRAÇÃO

Graduação em Administração de Empresas 


\section{Lucas Lopes Fernandes}

A influência do fanatismo do torcedor na intenção de compra de produtos licenciados por times de futebol

Trabalho de Conclusão de Curso

Trabalho de Conclusão de Curso, apresentado ao programa de graduação em Administração da PUC-Rio como requisito parcial para a obtenção do titulo de graduação em Administração.

Orientador(a) : Daniel Kamlot 
Agradecimentos

Aos meus pais, que me deram todo suporte mesmo em momentos difíceis. Sem vocês eu não conseguiria conquistar nada disso.

Ao meu professor/orientador Daniel Kamlot por todo o apoio e toda a assistência prestada durante todo o período.

A minha namorada por sempre acreditar em mim e me ajudar nos momentos mais difíceis, tendo paciência e me dando carinho.

Aos meus amigos que também estão sempre do meu lado, seja tornando a PUC um ambiente mais calmo e feliz, seja em outros lugares animando e tornando momentos mais especiais. 


\section{Resumo}

Fernandes, Lucas. A influência do fanatismo do torcedor na intenção de compra de produtos licenciados por times de futebol. Rio de Janeiro, 2019. Número de páginas $P$. Trabalho de Conclusão de Curso - Departamento de Administração. Pontifícia Universidade Católica do Rio de Janeiro.

Esse estudo buscou mostrar a influência do fanatismo por um time de futebol na intenção de compra de produtos licenciados (conveniência x compra comparada). Através de 111 participantes, somando 111 respostas do questionário foi possível observar a questão do valor dos produtos influenciando diretamente na intenção de compra. Além disso, o perfil do participante também influencia na importância e na amplitude do fanatismo, envolvendo questões benéficas e não benéficas para os seus clubes.

Além disso, esse texto aborda temas como Marketing Esportivo, 5 P's, Comportamento do Consumidor, mostrando a relevância do estudo e aplicação para os times de futebol.

\section{Palavras- chave}

Marketing Esportivo; Comportamento do Consumidor; Motivação; Futebol; Flamengo; Mercado de Produtos Licenciados.

\section{Abstract}

This study aimed to show the influence of fanaticism by a soccer team in the intention to purchase licensed products (convenience vs. compared purchase). Through 111 participants, adding 111 responses from the questionnaire, it was possible to observe the question of the value of the products directly influencing the purchase intention. In addition, the participant profile also influences the importance and breadth of fanaticism, involving issues that are beneficial and not beneficial to their clubs.

In addition, this text addresses themes such as Sports Marketing, 5 P's, Consumer Behavior, showing the relevance of study and application to football teams.

\section{Key-words}

Sports marketing; Consumer behavior; Motivation; Soccer; Flamengo; Licensed Products Market. 
1. O problema 8

1.1. Introdução 8

1.2. Objetivo Final 9

1.3. Objetivo Intermediários 9

1.4. Delimitação do Estudo 9

1.5. Relevância do Estudo 11

2 Referencial Teórico 12

2.1. Marketing Esportivo 12

2.2. Mercado de Produtos Licenciados 13

2.2.1. Produtos de Conveniência vs. Produtos de Compra Comparada 15

2.3. Comportamento do Consumidor 16

2.3.1. Motivação 16

$\begin{array}{ll}\text { 2.4. Processo de Decisão de Compra } & 17\end{array}$

3 Metodologia 19

$\begin{array}{ll}\text { 3.1. Tipos de Pesquisa } & 19\end{array}$

3.2. Universo e Amostra 19

3.3. Coleta de Dados 20

3.4. Tratamento de Dados 20

$\begin{array}{ll}\text { 3.5. Limitações do Estudo } & 21\end{array}$

4. Resultados 22

4.1. Perfil dos Participantes 22

4.2. Comportamento dos Torcedores 26

$\begin{array}{ll}5 \text { Conclusão } & 37\end{array}$

6 Referências Bibliográficas 39 


\section{Índice de Figuras}

Figura 1: Ranking de público no Campeonato Brasileiro de 2018. ................... 10

Figura 2: Ranking de receitas do ano 2017, em milhões de euros. ................... 10

Figura 3: Propaganda online feita pelo Clube do Flamengo. ............................ 14

Figura 4: Quantidade de produtos oficiais comprados por torcedor, anualmente. 14

Figura 5: Campanha online a favor dos produtos oficiais e licenciados............ 15

Figura 6: As 5 etapas do Processo de Decisão de Compra por Kotler (2006) ... 17 


\section{Índice de Gráficos}

Gráfico 1: Qual o time que o torcedor torce.............................................. 22

Gráfico 2: A orientação sexual dos participantes da pesquisa.......................... 23

Gráfico 3: Qual a idade dos participantes da pesquisa................................... 24

Gráfico 4: Qual o grau de instrução dos participantes da pesquisa. ................. 24

Gráfico 5: Qual o estado civil dos participantes da pesquisa.......................... 25

Gráfico 6: Qual o rendimento familiar mensal do participante da pesquisa........ 25

Gráfico 7: Qual a probabilidade do torcedor comprar uma caneca de chopp

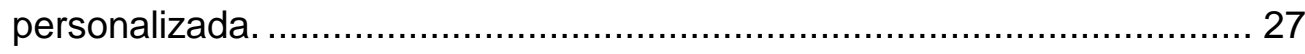

Gráfico 8: Qual a probabilidade do torcedor comprar uma cerveja personalizada.

Gráfico 9: Qual a probabilidade do torcedor comprar um relógio personalizado. 29

Gráfico 10: Qual a probabilidade do torcedor comprar um microondas

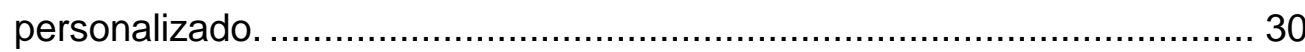

Gráfico 11: Qual a frequência que o participante assiste a jogos do seu time. .. 31

Gráfico 12: Quem possui produtos com o escuto dos seus times...................... 31

Gráfico 13: Qual a originalidade dos produtos que essas pessoas possuem. ... 32

Gráfico 14: Pergunta sobre o conhecimento a respeito das parcerias que acontecem entre os clubes e as empresas que licenciam os produtos vendidos pelo Flamengo................................................................... 33

Gráfico 15: Pergunta sobre a receita que é destinada ao clube com a venda dos produtos licenciados. ....................................................................... 34

Gráfico 16: Pergunta sobre a honestidade do torcedor: se ele compraria ou não produtos não oficiais mesmo sabendo que não estariam ajudando o seu

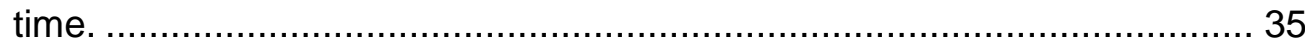

Gráfico 17: Qual é o grau de fanatismo do torcedor que respondeu o

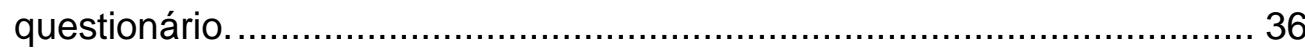




\section{O problema}

\subsection{Introdução}

Como se sabe, o futebol atrai atenção em todo o mundo, seja ele nacional ou internacional. De acordo com o site Correio Braziliense (2018), cerca de 1 bilhão de pessoas assistiu à Copa do Mundo da Rússia e um quarto dos brasileiros parou para assistir à sua abertura. Com isso, algumas situações extremas foram criadas e com o resultado dessas situações, surge o fanatismo. O torcedor fanático é aquele que sempre vai aos estádios, que está sempre conectado com o que está acontecendo com o time, que sempre sabe das contratações e das escolhas erradas que os dirigentes fazem, que sempre vê oportunidade e esperança e que nunca pode ouvir falar mal do seu time de paixão. É esse torcedor que é um potencial alvo para os clubes quando o assunto é retorno financeiro, porque o clube sabe que o seu fanatismo será responsável pelo fato desse torcedor não medir esforços em ajudar a instituição, seja na forma de comprar produtos ou de ser um Sócio Torcedor (torcedores que pagam uma mensalidade em troca de benefícios, como por exemplo, ingressos mais baratos), principalmente no Brasil, que é conhecido no mundo inteiro como o "país do futebol".

De acordo com a ABRAL - Associação Brasileira de Licenciamento (2017), o setor esportivo está em segundo lugar na lista das categorias que são mais procuradas para serem licenciadas, estando atrás apenas da categoria entretenimento, (diferença de $15 \%$ para $57 \%$, respectivamente). Além desse dado, a associação também informou que o Brasil está entre os seis países do mundo que mais faturam com esse mercado dos produtos licenciados, estando atrás dos Estados Unidos, Inglaterra, Canadá, Japão e México. O mercado movimentou no ano de 2016, R\$ 17 bilhões e no ano de 2017, R $\$ 18$ bilhões.

Justamente por causa desses dados os clubes nacionais vêm investindo cada vez mais neste mercado, visto que o número de torcedores só tende a crescer em clubes que possuem suas finanças equilibradas e que conquistam títulos, como o caso do Flamengo. De acordo com a Datafolha (2018), 18\% dos 
torcedores nacionais são flamenguistas e esses torcedores estão investindo cada vez mais no clube.

No ano de 2016 , esses $18 \%$ de torcedores nacionais do Flamengo foram responsáveis por $\mathrm{R} \$ 19,2$ milhões em vendas com esses produtos licenciados. Todos esses dados nos levam a um questionamento: Até que ponto a paixão pelo time de futebol influencia na aquisição de produtos de conveniência e de produtos de compra comparada?

\subsection{Objetivo Final}

Este estudo tem como objetivo final analisar a influência do fanatismo do torcedor pelo seu clube de futebol na intenção de compras de produtos de conveniência e de produtos de compra comparada, ou seja, verificar se os níveis de fanatismo existentes são responsáveis pela compra de certos produtos apenas por serem vinculados à marca do clube.

\subsection{Objetivo Intermediários}

- Identificar quais são os padrões de fanatismo dos torcedores pelos clubes de futebol;

- Identificar qual é o limite de um torcedor quando relaciona a compra de produtos licenciados e o seu time de futebol;

- Identificar quais são os produtos de conveniência e produtos de compra comparada preferidos pelos torcedores;

\subsection{Delimitação do Estudo}

Esse estudo está delimitado, pela parte do clube de futebol, ao Flamengo. Este possui uma torcida de 32,5 milhões no mundo, sendo o clube com mais torcedores do Brasil. Dos clubes do Rio, o Vasco aparece em 50 lugar, por exemplo. Outro fator de escolha foi o desempenho dentro de campo no ano de 2018, sendo o clube carioca que mais venceu clássicos no ano (2018), que foi melhor colocado nas competições nacionais e internacionais (2018), que obteve a maior média de público do ano (2018) e que teve a melhor receita do ano, segundo o site Globoesporte (2017). 


\begin{tabular}{|c|c|c|c|c|}
\hline equipe & média pagantes & ocupação média & renda bruta & ticket médio \\
\hline 플 Flamengo & 46.258 & $58 \%$ & $\mathrm{R} \$ 24.651 .237$ & $\mathrm{R} \$ 29$ \\
\hline Wrã São Paulo & 34.320 & $51 \%$ & $\mathrm{R} \$ 23.130 .263$ & $\mathrm{R} \$ 35$ \\
\hline (6) Palmeiras & 31.862 & $75 \%$ & $\mathrm{R} \$ 33.670 .934$ & $\mathrm{R} \$ 58$ \\
\hline Corinthians & 31.367 & $65 \%$ & $\mathrm{R} \$ 25.376 .679$ & $\mathrm{R} \$ 42$ \\
\hline$\odot$ Internacional & 27.701 & $55 \%$ & $\mathrm{R} \$ 16.034 .659$ & $\mathrm{R} \$ 30$ \\
\hline
\end{tabular}

Figura 1: Ranking de público no Campeonato Brasileiro de 2018.

Fonte: Site do Globoesporte (2017).

\section{TEMPORADA 2016/2017}

Ranking por Receita em Milhões de Euros

\begin{tabular}{|c|c|c|c|c|c|c|}
\hline Manchester United & $\oplus$ & 676 & 19 & Napoli & $\mathrm{O}$ & 201 \\
\hline 2 Real Madrid & (2) & 675 & 20 & Everton & $\oplus$ & 199 \\
\hline 3 Barcelona & (3) & 648 & 27 & Lyon & O & 198 \\
\hline 4 Bayern de Munique & $\Theta$ & 588 & 22 & Milan & O & 192 \\
\hline 5 Manchester city & $\oplus$ & 528 & 23 & Zenit & $\theta$ & 180 \\
\hline 6 Arsenal & $\oplus$ & 488 & 24 & Roma & O & 172 \\
\hline 7 PSG & O & 486 & 25 & B. Mönchenglodbach & $\theta$ & 169 \\
\hline 8 Chelsea & $\oplus$ & 428 & 26 & Crystal Palace & $\oplus$ & 164 \\
\hline 9 Liverpool & $\oplus$ & 424 & 27 & FLAMENGO & (2) & 161 \\
\hline 0 Juventus & O & 406 & 28 & West Bronwich & $\oplus$ & 161 \\
\hline 1 Tottenham & $\oplus$ & 356 & 29 & Bournemouth & $\oplus$ & 159 \\
\hline
\end{tabular}

Figura 2: Ranking de receitas do ano 2017, em milhões de euros.

\section{Fonte: Site do Globoesporte (2017)}

Já no caso dos produtos, este estudo vai se delimitar a 2 produtos de conveniência e 2 produtos de compra comparada. Os produtos de cada classe vão ser escolhidos baseados em quantidade de vendas, facilidade de acesso e preferencias. Os de conveniência, por serem mais baratos, serão escolhidos devido a popularidade. Já os de compra comparada, serão escolhidos devido a possibilidade de retorno financeiro para o clube. 


\subsection{Relevância do Estudo}

Este estudo, será importante para: (i) O Flamengo pois saberá detalhes do mercado de licenciamento e qual o retorno que este mercado traz para o clube; (ii) Também para os clubes em âmbito nacional, pois estes saberão como é o mercado nacional desses produtos e se vale o investimento; (iii) Para os empreendedores que estão procurando novas oportunidades e para os que já possuem seus negócios, em se situar na questão dos produtos licenciados, visando a uma possível associação com os clubes para a venda desses produtos.

Outra grande oportunidade, que não serve apenas para os clubes e sim para o mercado geral do Brasil, é a chance de identificar e estudar o comportamento desse consumidor que estamos chamando de "fanático" e qual é o seu limite de compra quando o assunto é o seu fanatismo pelo clube de coração, identificando assim oportunidades de mercado para todos os times, inclusive os menores, que não possuem tanto retorno de patrocínios e de cotas de televisão, por exemplo. 


\section{Referencial Teórico}

Neste capítulo de Referencial Teórico, vamos observar os conceitos que embasaram a pesquisa. Foi dividida em: Marketing Esportivo, Paixão pelo Clube, Mercado de Produtos Licenciados, Comportamento do Consumidor, Processos de Decisão de Compra.

\subsection{Marketing Esportivo}

De início, "Marketing Esportivo consiste em todas as atividades destinadas a atender às necessidades dos consumidores de esporte por meio de um processo de intercâmbio". (MULLIN, HARDY e SUTTON, 1996, p.49). Somada a essa definição, "Marketing Esportivo é o processo de elaborar e implementar atividades de produção, formação de preço, promoção e distribuição de um produto esportivo para satisfazer as necessidades ou desejos de consumidores e realizar os objetivos da empresa" (PITTS e STOTLAR, 2002, p. 90). Ou seja, esta atividade pode ser considerada todo o processo de pré e pós venda ou serviço, sendo aplicada a todos os produtos do mundo esportivo.

"O marketing esportivo está cada vez mais presente em nossas vidas, profissionalizando entidades esportivas, tornando possível a realização de eventos cada vez mais organizados, vendendo cada vez mais produtos ligados ao esporte, beneficiando a imagem de empresas e proporcionando o devido suporte técnico e financeiro aos atletas, que tornam tudo isso possível" (POZZI, 1998, p. 22).

Além disso, "o esporte lida com a emoção, tem também um aspecto imaterial, de orgulho, vibração, satisfação, alegria, derrota, frustração, esperança de uma volta por cima, etc." (NOGUEIRA, 2010, p. 15), ou seja, o fato do Marketing ter gerado o Marketing Esportivo é explicado pelo fato de haver emoção pelo esporte, seja material ou imaterial. Seguindo essa mesma linha de pensamento, segundo Nogueira (2010) o marketing esportivo é dividido em diferentes formas de atuação: O Marketing do Esporte em si, que é baseado no conceito de que "as instituições esportivas usam técnicas de marketing para atender ao público e gerar receita" (NOGUEIRA, 2010, p. 16) e o Marketing 
através do esporte, que no caso são propagandas e divulgações feitas em eventos esportivos, por exemplo.

Segundo uma subdivisão do autor brasileiro Afif (AFIF, 2000, p.17): "A atuação do Marketing esportivo ocorre de duas formas: a primeira é através do Marketing de produtos e serviços voltados aos consumidores que, de alguma forma, se relacionam com o esporte (campanha sócio torcedor do São Paulo F.C, venda de camisas oficiais dos times de futebol, etc.). A segunda consiste na estratégia que emprega o esporte como meio de divulgar produtos sem que estes tenham ligação com atividades esportivas...".

Algumas empresas e marcas que são líderes de mercado geralmente optam por esta área, usando a boa imagem de atletas e equipes esportivas, junto à opinião pública, para gerar resultados positivos para as imagens após as campanhas. Nesse sentido, Afif (2000) afirma que, atualmente, profissionais de marketing precisam de muita criatividade para se sobressair à publicidade tradicional, inovando com algo que tenha o poder de influenciar as pessoas. E é justamente nesse momento que o papel do marketing esportivo é atingido, quando chega aos olhos e ouvidos do torcedor ou do simples comprador.

\subsection{Mercado de Produtos Licenciados}

Buscando uma diferente forma de receita, aproximação com seus torcedores e um combate à pirataria, os clubes nacionais de futebol voltam suas atenções para o mercado de produtos licenciados e franquias, sempre modelados pelo futebol europeu, em que as lojas são os principais canais de acesso aos times.

A grande intenção dos clubes brasileiros é atingir a maior parte do seu público ou simpatizantes. Hoje em dia, uma camisa de futebol custa em torno de $R \$ 149,00$ a $R \$ 279,00$, um valor alto quando considerada a realidade de torcedores de classe B, C, D e E. Visto isso, esses clubes estão investindo em produtos mais baratos, como por exemplo uma caneca que custa em torno de $R \$ 19,00$. Outro exemplo seria um caderno, custando em torno de $R \$ 29,00$.

Nas principais instituições de futebol do Brasil, as 12 maiores (Flamengo, Vasco, Fluminense, Botafogo, São Paulo, Corinthians, Palmeiras, Santos, Cruzeiro, Atlético Mineiro, Internacional e Grêmio) possuem dois tipos de licenciamentos: (i) Os produtos que são feitos pelo próprio clube; (ii) os produtos que são feitos por outras empresas e licenciados pelo clube. 


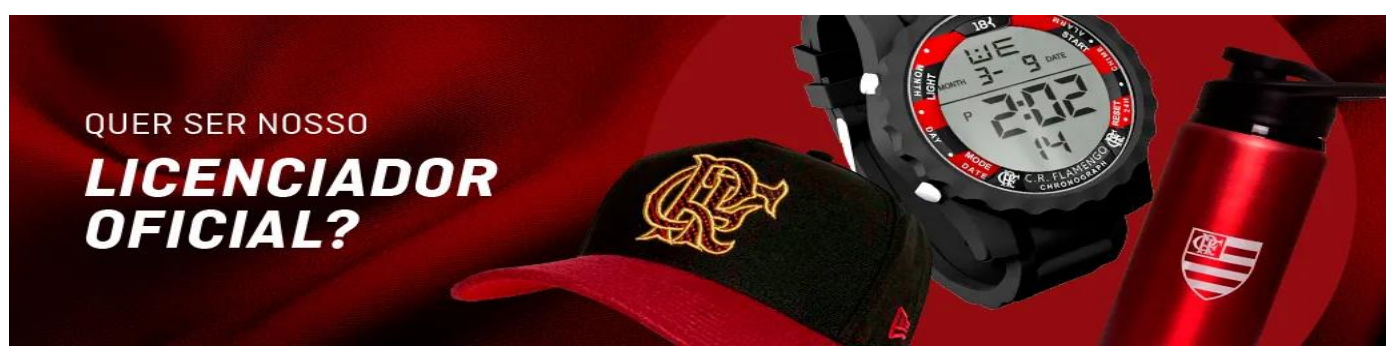

Figura 3: Propaganda online feita pelo Clube do Flamengo.

\section{Fonte: Site oficial do Flamengo (2018)}

Na figura 4, uma campanha feita pelo Flamengo no ano de 2018, através do seu site oficial, na qual estava recrutando empresas e vendedores para serem um dos licenciadores oficiais do clube.

De acordo com a CNDL (Confederação Nacional de Dirigentes Lojistas, 2016), no ano de 2016, foi realizada uma pesquisa nacional, em que a média de compra de produtos oficiais por torcedor, no mesmo ano, era de 4,4 produtos, sendo para os homens 4,6 e para as mulheres 4,1. Outra subdivisão que feita foi em relação ao torcedor, sendo caracterizado em: Aficionado, Fã Intenso e Simpatizante $(4,8 ; 3.9 ; 3,3$, respectivamente).

\begin{tabular}{|c|c|c|c|c|c|c|}
\hline \multirow[b]{2}{*}{ RU } & \multirow[b]{2}{*}{ Geral } & \multicolumn{2}{|c|}{ Sexo } & \multicolumn{3}{|c|}{ Torcedor } \\
\hline & & Homem & Mulher & Aficionado & Fa Intenso & Simpatizante \\
\hline Média & 4,4 & 4,6 & 4,1 & $4,8 \uparrow$ & 3,9 & 3,3 \\
\hline 1 produto & $7,1 \%$ & $7.2 \%$ & $6.8 \%$ & $6.8 \%$ & $6.8 \%$ & $9.0 \%$ \\
\hline 2 produtos & $11,6 \%$ & $10,1 \%$ & $14,2 \%$ & $14,4 \%$ & $8,5 \%$ & $9,6 \%$ \\
\hline 3 produtos & $11,3 \%$ & $10,6 \%$ & $12,5 \%$ & $12,5 \%$ & $11,2 \%$ & $6,9 \%$ \\
\hline 4 produtos & $11,8 \%$ & $12.6 \%$ & $10,5 \%$ & $13.9 \%$ & $12,3 \%$ & $2.8 \% \downarrow$ \\
\hline 5 produtos & $10,1 \%$ & $10,2 \%$ & $9,9 \%$ & $10,5 \%$ & $12.5 \%$ & $1,7 \% \downarrow$ \\
\hline 6 produtos & $6.0 \%$ & $5,4 \%$ & $6.9 \%$ & $7,9 \%$ & $4.5 \%$ & $2.9 \%$ \\
\hline 7 produtos & $1,3 \%$ & $1,4 \%$ & $1,2 \%$ & $1,5 \%$ & $1,5 \%$ & - \\
\hline 8 produtos & $2,3 \%$ & $2,4 \%$ & $2,0 \%$ & $3,4 \%$ & $0,6 \%$ & $2,8 \%$ \\
\hline 9 produtos & $0.3 \%$ & - & $0,8 \%$ & $0.2 \%$ & $0.5 \%$ & $0.3 \%$ \\
\hline 10 produtos & $2,7 \%$ & $4,0 \% \uparrow$ & $0,4 \%$ & $4,5 \%$ & $1,1 \%$ & - \\
\hline mais de 10 & $4,4 \%$ & $4,7 \%$ & $4,0 \%$ & $7,8 \% \uparrow$ & $0,9 \%$ & $1,1 \%$ \\
\hline $\begin{array}{l}\text { Nâo compro produtos } \\
\text { relacionados ao meu time }\end{array}$ & $13.2 \%$ & $13,9 \%$ & $11,9 \%$ & $6,4 \% \downarrow$ & $16,5 \%$ & $29,8 \%$ \\
\hline Năo sei/nåo lembro & $17,9 \%$ & $17,3 \%$ & $18,9 \%$ & $10.1 \% \downarrow$ & $23.2 \%$ & $33.2 \%$ \\
\hline
\end{tabular}

Figura 4: Quantidade de produtos oficiais comprados por torcedor, anualmente.

Fonte: CNDL (2016) 
Na figura 5 está outra campanha feita no ano de 2019, pelo clube do Flamengo, agora incentivando a não compra de produtos falsos, contra a pirataria. O interessante nessa campanha é enfatizar que os produtos não oficiais prejudicam o clube, portanto o torcedor que gosta do time deve comprar produtos oficiais e licenciados, ajudando assim na renda mensal.

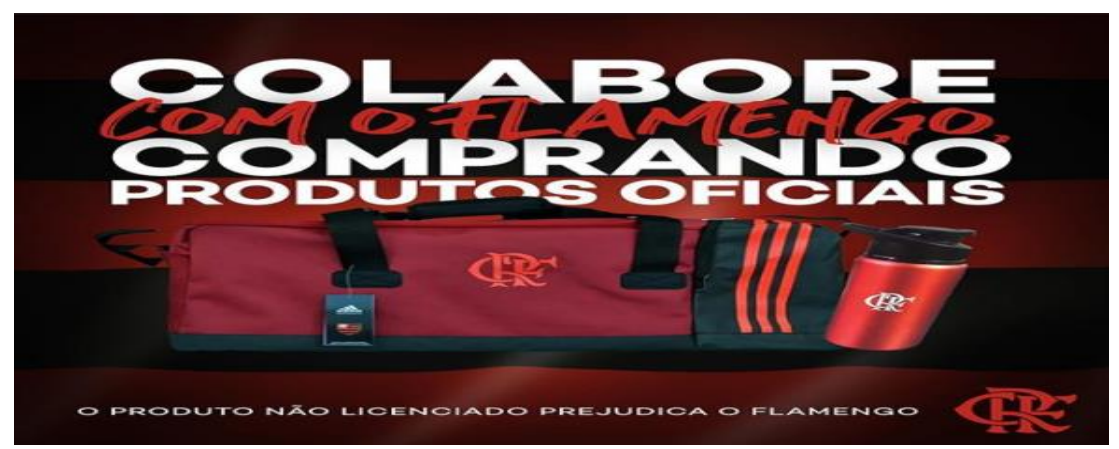

Figura 5: Campanha online a favor dos produtos oficiais e licenciados.

Fonte: Página online do Flamengo no Instagram (2019)

Para o licenciado também é benéfico em diversas situações. Como por exemplo: O licenciado é de uma cidade pequena onde não tem muito acesso a jogos. O comprador vai se esforçar para ter um produto do time que ama já que não assiste ao vivo a jogos com frequência. Já numa escala maior, uma loja que vende artigos licenciados pelo Flamengo em uma cidade grande, como no Rio de Janeiro. Existem lojas, dentro de shoppings, que só vendem produtos licenciados de times de futebol a nível brasileiro. Pessoas procuram essas lojas por terem mais comodidade e facilidade para comprar tais produtos.

\subsubsection{Produtos de Conveniência vs. Produtos de Compra Comparada}

De acordo com Kotler e Armstrong (2007), os produtos de conveniência e os produtos de compra comparada, são classificados como Produtos de Consumo. Porém, dentro dessa categoria, existem outros subtópicos com características diferentes: Produtos de Conveniência, Produtos de Compra Comparada, Produtos de Especialidades e Produtos Não Procurados. Neste tópico, serão explicados os dois primeiros: 
- Conveniência: "são artigos que o consumidor geralmente compra com frequência, rapidez e comparação e esforços mínimos." KOTLER (2007).Exemplos desses produtos, trazidos para 0 Esporte: canecas e chaveiros.

- Comparada são produtos de consumo comprados com menor frequência, e cujas características de adequabilidade, preço, qualidade e estilo são comparadas cuidadosamente pelo comprador. Ao adquirir esses produtos, os consumidores gastam muito tempo e esforço na busca por informações e fazendo comparações. KOTLER (2007). Exemplos desses produtos, também trazidos para o Esporte: relógios e caixões.

\subsection{Comportamento do Consumidor}

Inicialmente, para conseguir vender um produto para o cliente certo, é necessário entender um pouco mais do seu cliente. Desta forma, as empresas investem em comportamento do consumidor como forma de entendimento do seu público, e para o futebol não é diferente.

Nos grandes clubes, os responsáveis por cada área tentam entender o que os seus clientes procuram e o que os induz à compra. Segundo Churchill e Peter (2000), o comportamento de compra abrange os sentimentos, pensamentos e ações dos consumidores e as influências sobre eles que determinam transformações em seu comportamento de compra dentro do mercado em que estão inseridos.

\subsubsection{Motivação}

A motivação é um processo interno que precisa ser induzido e enfatizado por quem está vendendo. É uma importante estratégia, que se bem feita, estimula o comprador a adquirir o produto ou serviço. Segundo Solomon (2008), "a motivação refere-se aos processos que fazem com que as pessoas se comportem do jeito que se comportam. Ela ocorre quando uma necessidade é despertada e o consumidor deseja satisfazê-la". Ou seja, a motivação precisa estar presente desde a pré compra até a pós compra dos produtos.

É necessário saber, também, as intenções e o que levou o futuro cliente a pensar em adquirir tal produto e entender melhor a "cabeça" do cliente. 
Seguindo esse mesmo conceito, a administração de marketing, de acordo com Kotler e Keller (2006, p. 183-184), considera três teorias da motivação: a) teoria da motivação de Freud: Freud assumiu que as forças psicológicas reais que moldam o comportamento das pessoas são inconscientes. Assim, as pesquisas conduzidas tendo por base esta teoria têm levado a hipóteses muito interessantes, como: os consumidores resistem às ameixas secas porque elas são enrugadas e lembram pessoas velhas; os homens chupam charutos como uma versão adulta de chupar o dedo e outros; b) teoria da motivação de Maslow: para Maslow, as necessidades humanas são organizadas numa hierarquia, partindo das mais urgentes às menos urgentes. Maslow chegou a esta conclusão buscando responder por que as pessoas são dirigidas por certas necessidades em ocasiões específicas; c) teoria da motivação de Herzberg: desenvolveu a teoria dos dois fatores: insatisfatórios (aqueles que causam a insatisfação) e satisfatórios (aqueles que causam a satisfação). São duas as implicações de tais teorias: primeiro, devem-se evitar os fatores que causam a insatisfação; depois, identificar os fatores que causam a satisfação.

\subsection{Processo de Decisão de Compra}

Kotler (2006) utiliza o modelo de 5 etapas para explicar todo esse processo. "O consumidor passa por cinco etapas: reconhecimento do problema, busca de informações, avaliação de alternativas, decisão de compra e comportamento pós-compra" (KOTLER; KELLER, 2006, p. 189). O Processo de Decisão de Compra pode ser ilustrado na figura 8:

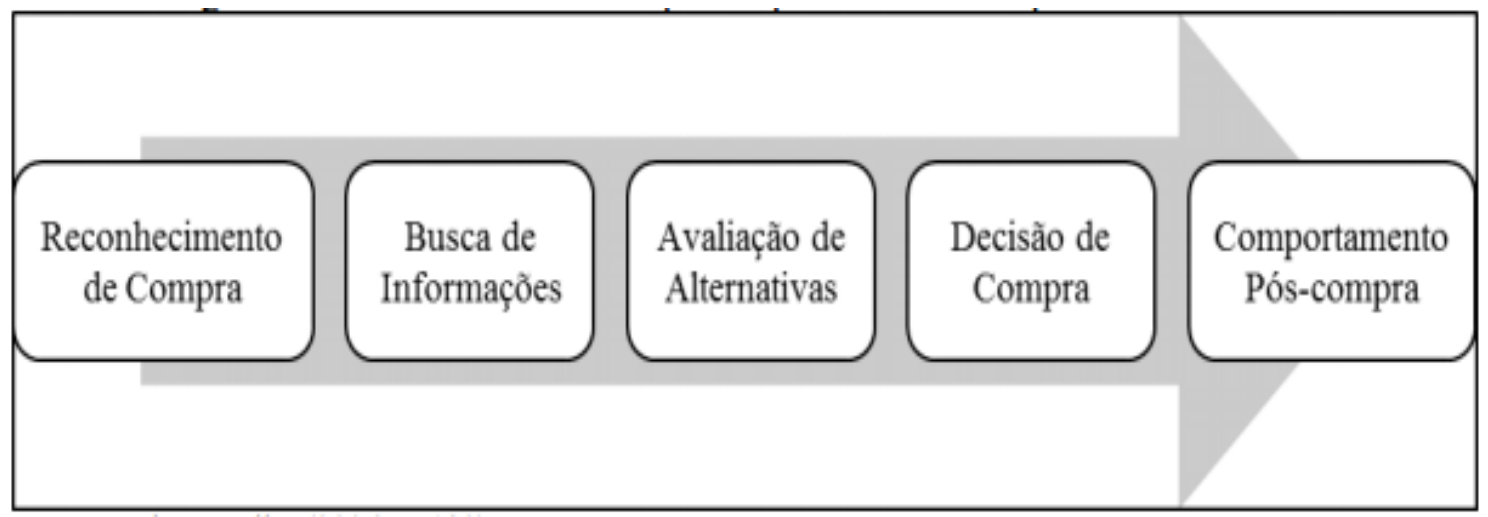

Figura 6: As 5 etapas do Processo de Decisão de Compra por Kotler (2006)

Fonte: Kotler e Keller. Administração e Marketing. 2006 
A primeira etapa é a do Reconhecimento de Compra, pois segundo Kotler e Keller (2006, p. 189), o processo de compra começa quando o comprador reconhece um problema ou uma necessidade. A necessidade pode ser provocada por estímulos internos ou externos." Os estímulos internos, como a fome, sede, necessidades físicas. Já os externos, como as percepções que os outros têm sobre as situações externas, como por exemplo admirações à casa dos vizinhos ou simplesmente assistir um comercial na televisão.

Logo após, vemos a Busca de Informações, que é a pesquisa feita pelo consumidor acerca do produto de sua necessidade. Essa pesquisa pode ser efetiva, de fato pesquisando sobre o mercado e preços, por exemplo ou apenas recebendo informações que chegam até ele, através de amigos ou notícias, que variam de acordo com a categoria dos produtos e as características do comprador, ainda segundo Kotler e Keller (2012).

A terceira etapa é a Avaliação de Alternativas, que de acordo com Kotler e Keller (2006, p. 191), "não existe um processo único de avaliação, os modelos mais atuais consideram que o consumidor forma julgamentos principalmente em uma base racional e consciente." Ao avaliar esses diferentes modelos de compra, o consumidor escolhe baseado em suas experiências e preferências.

$\mathrm{Na}$ penúltima fase, ocorre a Decisão de Compra, na qual "os consumidores não adotam necessariamente um único tipo de regra de escolha em suas decisões de compra" (KOTLER e KELLER, 2012, p. 184). Ao decidir que vai realizar a compra, existe a decisão por marca, decisão por revendedor, decisão por quantidade, decisão por ocasião e decisão por forma de pagamento. Essas 5 decisões ocorrem também baseadas em preferências e experiências próprias além de informações de terceiros. Após essas decisões, o consumidor de fato realiza a compra.

Por fim, o Comportamento Pós Compra, em que ao utilizar o produto, o consumidor tira suas próprias conclusões baseadas na sua experiência. Ele pode ter três ações: retornar e comprar novamente o produto; desistir ou devolvê-lo e por fim, reclamar em redes sociais ou órgãos especializados para tal. 


\section{Metodologia}

\subsection{Tipos de Pesquisa}

De acordo com Gil (2008), qualquer classificação de pesquisa deve seguir algum critério. Se utilizarmos o objetivo geral como critério, teremos três grupos de pesquisa:

1. Pesquisas Exploratórias

2. Pesquisas Descritivas

3. Pesquisas Explicativas

Nesse artigo, foi utilizada a pesquisa Exploratória, que tem o objetivo de familiarizar um assunto pouco explorado, pouco conhecido. Ao final dessa pesquisa, você poderá tirar suas conclusões e construir hipóteses. Por ser um tipo de pesquisa muito específica, quase sempre ela assume a forma de um estudo de caso (GIL, 2008). Além dessa, a Pesquisa Descritiva também se fez presente. De acordo com Gil (2008), as pesquisas descritivas possuem como objetivo a descrição das características de uma população, fenômeno ou de uma experiência. Por exemplo, nessa pesquisa, quais as características de um determinado grupo em relação a time que torce, idade, renda familiar, fanatismo, entre outros assuntos. Ao final dessa pesquisa, geralmente é analisado todos os dados e tem a disposição inúmeras informações sobre o assunto.

\subsection{Universo e Amostra}

O universo foi restringido à torcedores do Flamengo, devido a sua maior quantidade, não só na pesquisa, como no Rio de Janeiro e Brasil. A amostra final foi de 111 pessoas, resultado da quantidade de pessoas que responderam 0 questionário. Essa amostra é não probabilística, escolhida por facilidade de acesso. 


\subsection{Coleta de Dados}

A coleta dos dados foi feita através de pesquisas bibliográficas, devido ao estudo ter sido feito baseado em livros, revistas, sites online, teses e artigos. A intenção foi de conseguir o maior número de dados e informações para embasar ainda mais a pesquisa, dando mais credibilidade para o leitor confiar no que foi passado.

Logo após o referencial teórico, foi criada uma pesquisa, através de um questionário com 17 perguntas, disparada para o público através da internet. Esse questionário era dividida em partes. A primeira era sobre as informações pessoais: Idade, Sexo, Time para qual torce, Renda Familiar e Grau de Instrução. Nessa etapa, o colaborador passava em qual situação ele se encontrava para que fossem montados os grupos baseados nas respostas. $\mathrm{Na}$ segunda parte, foram criadas 4 perguntas sobre 2 produtos conveniência e 2 de compra comparada (caneca de chopp, cerveja, relógio e um microondas). Para complementar, foi incluída a Escala de Juster, onde as opções ajudam a termos uma maior certeza na conclusão das informações. Na terceira e última parte, 7 perguntas de múltipla escolha, com 5 respostas possíveis, para editar e embasar ainda mais o perfil de cada pessoa.

\subsection{Tratamento de Dados}

O tratamento de dados foi feito através de um modo quantitativo, realizado por meio de estatística descritiva, com cálculo de média, moda, desviopadrão através de um questionário, enviado para centenas de pessoas, onde 111 pessoas enviaram suas respostas. Nesse questionário, as pessoas opinaram sobre produtos licenciados com a marca do Flamengo e por fim responderam 7 perguntas sobre fanatismo. Foram obtidas informações numéricas sobre o comportamento do consumidor. Este método é conclusivo e tem como objetivo quantificar um problema e entender sua dimensão. 


\subsection{Limitações do Estudo}

Essa pesquisa, como qualquer outra, possui limitações. Uma delas é que os resultados da mesma estão limitados ao público alvo desta pesquisa, apenas.

Por fim, o respondente pode ser parcial em suas respostas, por ter preferência pelo time de coração ou por ser muito contra ao time e exemplos em questão. A paixão pelo time influencia diretamente nas respostas. 


\section{Resultados}

Este capítulo, organizado em duas seções, vai apresentar e discutir os principais resultados coletados, além de analisar suas implicações e concluir as informações com os resultados analisados.

A primeira seção apresenta e descreve o perfil dos participantes e a segunda seção vai apresentar os seus comportamentos.

\subsection{Perfil dos Participantes}

Foram coletadas 111 respostas de 111 participantes diferentes. Por ordem das perguntas presentes no questionário, 79 desses participantes são flamenguistas, resultando em uma maioria de $71,2 \%$ do total de torcedores; em seguida, temos 16 torcedores do Fluminense com 14,4\%; depois, em terceiro, temos os torcedores do Botafogo, totalizando 11 participantes e 9,9\% do total; por último os torcedores do Vasco, com 5 torcedores e totalizando 4,5\% das 111 respostas. No formulário havia um espaço caso alguém não torcesse primeiramente para nenhum dos quatro grandes times do Rio de Janeiro, porém não houve nenhum voto.

Por qual time você torce:

111 respostas

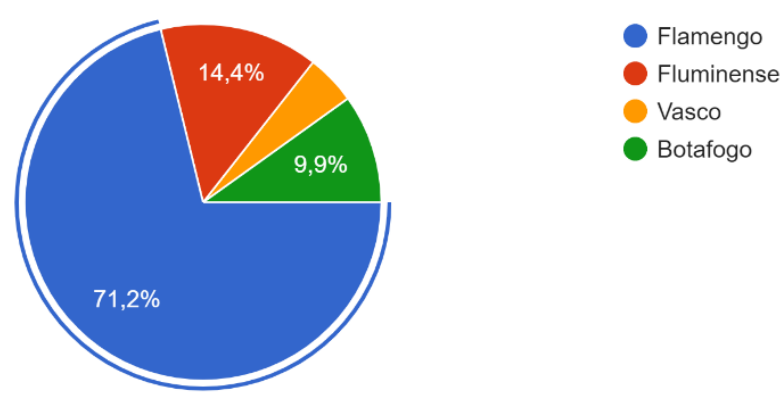

Gráfico 1: Por qual o time que o torcedor torce.

Fonte: Pesquisa de campo (2019). 
A segunda pergunta foi relacionado ao gênero dos participantes: 91 participantes são homens (82\%) e 20 são mulheres (18\%), uma diferença bem grande, pois menos de $1 / 4$ das respostas foram femininas, o que ilustra os resultados por todo o Brasil, onde o Futebol Feminino é marginalizado e inferiorizado quando comparado com o Futebol Masculino.

Sexo:

111 respostas

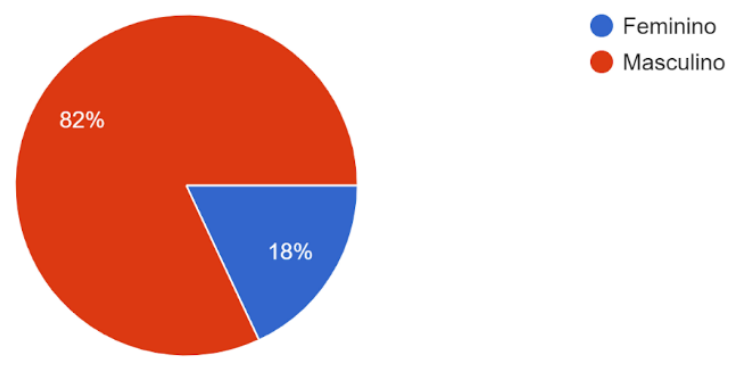

Gráfico 2: $O$ gênero dos participantes da pesquisa.

Fonte: Pesquisa de campo (2019).

Logo em seguida, os participantes foram questionados sobre as respectivas idades. Uma grande maioria está situada entre as idades de 22 a 26 anos (aproximadamente $66 \%$ dos participantes). Após o fim das respostas, a média de idade foi de 26,4 anos, o que representa muito bem a 4 a pergunta que era sobre o grau de instrução dos participantes. E, como o esperado, a maioria dos participantes respondeu: Superior Incompleto, ou seja, ainda não terminaram a faculdade. O total de pessoas com esse grau é de 51, resultando em 45,9\%. Uma grande parcela também respondeu Superior Completo, totalizando $32,4 \%$, visto que a média de idade de ingresso nas faculdades em geral é de 24,2 anos e a de conclusão é de 28,2, segundo o Resumo Técnico do Censo da Educação Superior 2016, feito pelo INEP (Instituto Nacional de Estudos e Pesquisas Educacionais Anísio Teixeira ) e Ministério da Educação, esses números estão dentro do padrão. 
Idade

111 respostas

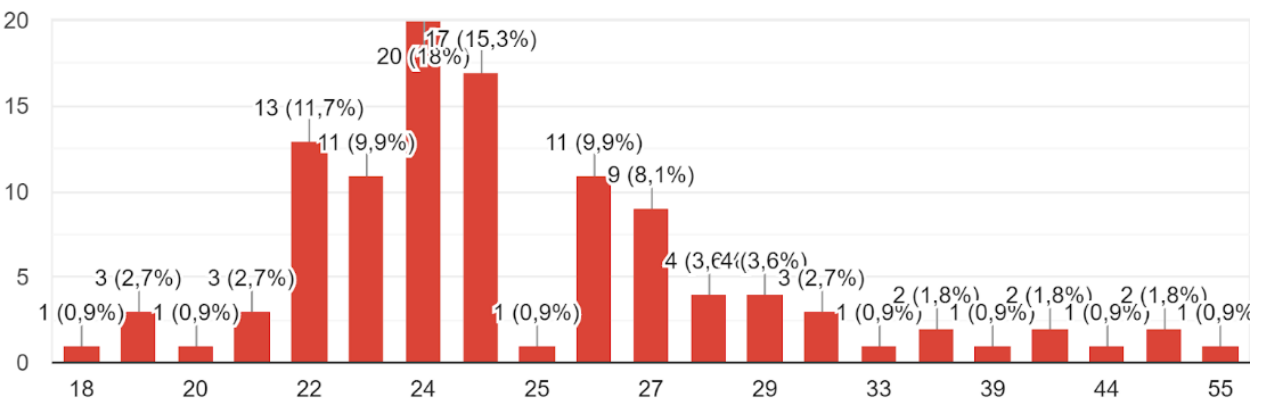

Gráfico 3: Qual a idade dos participantes da pesquisa.

Fonte: Pesquisa de campo (2019).

Grau de Instrução:

111 respostas

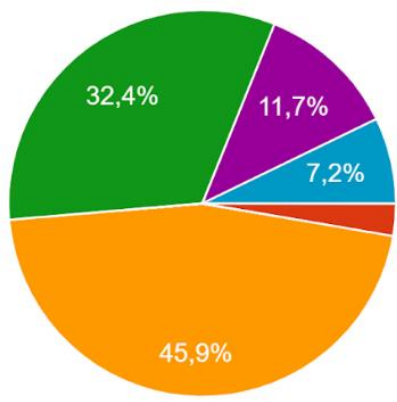

Fundamental Incompleto

Fundamental Completo

Superior Incompleto

Superior Completo

Pós Graduação Incompleto

Pós Graduação Completo

Gráfico 4: Qual o grau de instrução dos participantes da pesquisa.

Fonte: Pesquisa de campo (2019).

Também de acordo com a média de idade e o grau de instrução, o Estado Civil foi o próximo questionamento que entrou na média. A grande maioria respondeu solteiro, mais de $84 \%$, totalizando 94 pessoas. Houve um número pequeno de Casados, totalizando 12 pessoas e um percentual de 10,8\%. O número de separados e viúvos foi insignificante, 4 pessoas e 3,6\% e 1 pessoa com $0,9 \%$, respectivamente. 
Estado Civil:

111 respostas

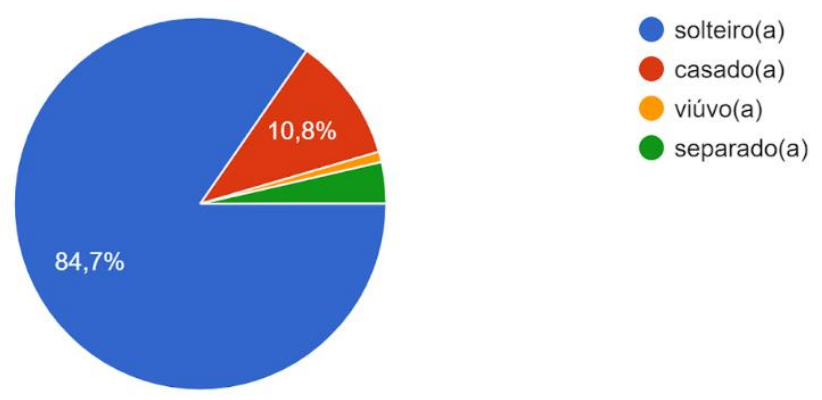

Gráfico 5: Qual o estado civil dos participantes da pesquisa.

Fonte: Pesquisa de campo (2019).

Por fim, o Rendimento Familiar. Também resultante de todas as categorias acima, somados com o perfil dos moradores da Zona Sul, onde está localizada uma grande porcentagem dos participantes, temos como maioria a mais de $R \$ 23.345,11$, com $34,2 \%$. Com uma porcentagem muito parecida, a entre $R \$ 10.386,52$ e $R \$ 23.345,11$, com $33,3 \%$. Seguidos pela $R \$ 5.363,52$ até $R \$ 10.386,52$, com $16,2 \%$ e a entre $R \$ 2.965,69$ e $R \$ 5.363,19$, com $13,5 \%$. Ou seja, 75 pessoas ou $67,5 \%$ das pessoas recebem mais de $R \$ 10.386,52$ por mês.

Rendimento Familar:

111 respostas

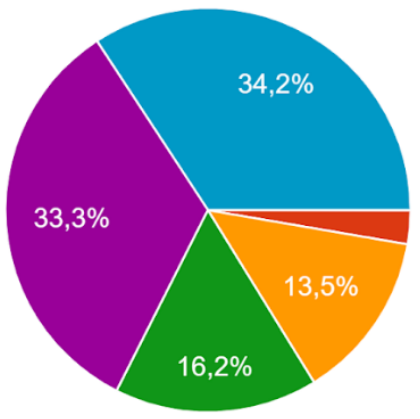

D/E até C2: Entre R\$708,19 até R\$ $1.691,44$

C2 até $\mathrm{C} 1$ : Entre $\mathrm{R} \$ 1.691,44$ até $\mathrm{R} \$$ $2.965,69$

C1 até B2: Entre R\$2.965,69 até R\$ $5.363,19$

B2 até B1: Entre R\$ 5.363,19 até R\$ $10.386,52$

B1 até $A:$ Entre $R \$ 10.386,52$ até $R .$.

Superior a $A$ : Mais de $R \$ 23.345,11$

Gráfico 6: Qual o rendimento familiar mensal do participante da pesquisa.

Fonte: Pesquisa de campo (2019) 


\subsection{Comportamento dos Torcedores}

As quatro primeiras perguntas do questionário, para iniciarmos a análise, foram feitas utilizando a Escala de Juster. Esta é uma escala de probabilidade de 11 pontos, onde o 0 é nenhuma chance de comprar e o 10 é com certeza compraria. Foram apresentados quatro produtos, dois de conveniência (cerveja e caneca de chopp) e dois de compra comparada (relógio e microondas). Segundo a Forethought Reserch (2018), a Escala de Juster, em muitas das suas aplicações, é superior quando relacionada a comparação de medidas preditivas de compra comparada. A escala funciona da seguinte forma: a resposta mais positiva, mais otimista é a "com certeza compraria" e vale 10 pontos por resposta. Ou seja, se $X$ pessoas optaram por essa resposta, seu valor na escala seria 10 multiplicado por $X$ pessoas. A segunda mais otimista é a quase com certeza compraria. Esse vale 9 pontos na escala. Assim vai até chegar a mais pessimista, que é a nenhuma chance de comprar, que vale 0 pontos na escala. Ao final dessa soma, teremos $Y$ como resultado. Pegamos esse resultado e colocamos na forma de porcentagem (Y\%). Quanto maior a porcentagem, maior a chance de compra de tal produto.

\section{- Caneca de chopp:}

Começamos por esse produto. A sua pontuação foi 573 somando os 111 resultados. Como média, 5,162, ou seja, 51,62\% das pessoas comprariam a caneca de chopp. Analisando o gráfico 7 , a porcentagem das pessoas que com certeza comprariam é bem semelhante às que nunca comprariam, 26,1\% e $24,3 \%$, respectivamente (totalizando $50,4 \%$, a metade praticamente). Porém, o que está entre essas duas respostas, correspondem a outra metade, portanto, influenciam tanto quanto as anteriores. 
Qual a probabilidade de você comprar essa caneca de chopp personalizada pelo Flamengo?

111 respostas

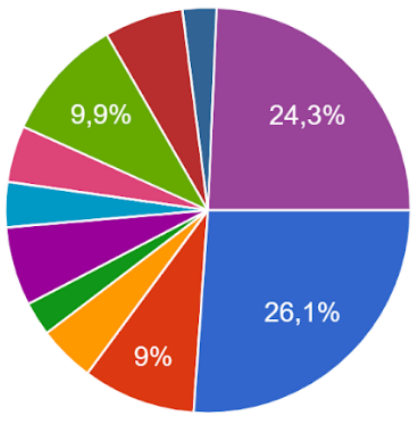

Com certeza compraria

Quase com certeza compraria

Muito provável que compre

Provável que compre

Boa probabilidade de que compre

Razoável probabilidade de que com..

Alguma probabilidade de que compre

Pouca probabilidade de que compre

\section{Gráfico 7: Qual a probabilidade do torcedor comprar uma caneca de} chopp personalizada.

Fonte: Pesquisa de campo (2019).

\section{- Cerveja da Brahma em parceria com o Flamengo:}

Já o segundo produto era uma cerveja (bebida alcoólica) da marca Brahma em parceria com a instituição do Flamengo. A soma de todos os resultados foi 676 pontos. Quando divididos por 111, temos a média de 6,09. Com isso, 60,9\% das pessoas comprariam esse produto. Nessa pergunta não tivemos a resposta "Alguma probabilidade de que compre". O somatório de pessoas que comprariam passa de $50 \%$ ( com certeza, quase com certeza e que comprariam). Já no contrário, de pessoas que não comprariam, não passa de $40 \%$, por isso que a porcentagem é mais alta que a anterior.

Esse alto índice é devido ao fato de que são produtos de conveniência, ou seja, produtos mais baratos que são mais acessíveis ao público. A cerveja, principalmente, teve um grau maior porque é algo que um não flamenguista também ingere. Essas latinhas são vendidas em sua maioria nos jogos do Flamengo ou em promoções em redes de supermercados e por ser uma marca conhecida, a Brahma fez um apelo aos torcedores dos 4 grandes do Rio de Janeiro. Essa parceria existe com os 4 clubes, de acordos e rendimentos diferentes, porém todas com a mesma intenção: alcançar o máximo de pessoas possível. 
Em suas redes sociais, o Flamengo visa aproximar a cerveja à marca do Flamengo, lançando campanhas em suas redes sociais, em que o sócio torcedor do clube tem descontos nas latinhas da marca Brahma.

Abaixo temos o gráfico 8 com os resultados mencionado no texto.

Qual a probabilidade de você comprar essa cerveja da marca Brahma em parceria como Flamengo?

111 respostas

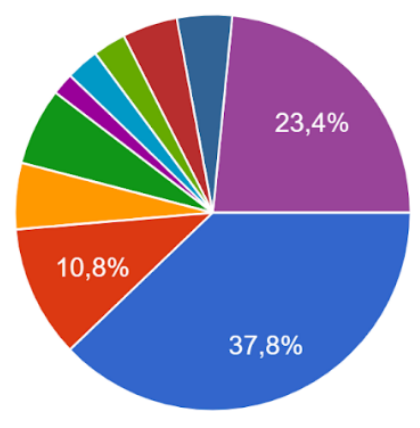

Com certeza compraria

Quase com certeza compraria

Muito provável que compre

Provável que compre

Boa probabilidade de que compre

Razoável probabilidade de que com...

Alguma probabilidade de que compre

Pouca probabilidade de que compre

$1 / 2 \nabla$

\section{Gráfico 8: Qual a probabilidade do torcedor comprar uma cerveja} personalizada.

Fonte: Pesquisa de campo (2019).

- Relógio da marca Technos com parceria do Flamengo:

O terceiro objeto foi o relógio. Nenhuma resposta "Insignificante probabilidade de que compre" foi obtida. O resultado da soma foi 458 . Como média, 4,13. A porcentagem de pessoas que comprariam foi de $41,3 \%$, uma porcentagem baixa, menor que 50\%. Provavelmente isso já se dá devido ao fato de que o relógio, que é um produto de compra comparada, é mais caro que os outros produtos. Segundo o site Espaço Rubro Negro (2019), este produto custa aproximadamente $R \$ 300,00$, existindo outros modelos que vão de $R \$ 249,00$ até $R \$ 399,00$. No site oficial do Flamengo, encontram se produtos que chegam a custar $\mathrm{R} \$ 899,00$.

Esses valores servem para mostrar que ao comparar com a cerveja, por exemplo, essa diferença de valores fica "desleal". Para o torcedor, independente da classe socio econômica, comprar um simples produto de $R \$ 5,00$ reais é muito diferente de comprar um de $\mathrm{R} \$ 249,00$ no melhor dos casos. 
Qual a probabilidade de você comprar esse relógio da marca Technos em parceria com o Flamengo?

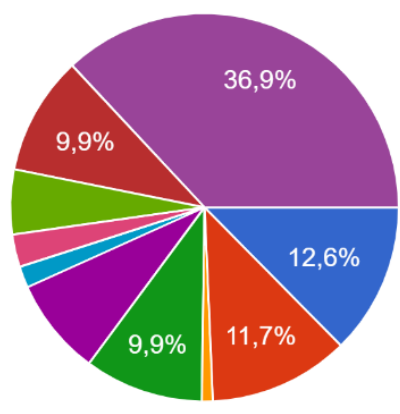

Com certeza compraria

Quase com certeza compraria

Muito provável que compre

Provável que compre

Boa probabilidade de que compre

Razoável probabilidade de que com...

Alguma probabilidade de que compre

Pouca probabilidade de que compre

\section{Gráfico 9: Qual a probabilidade do torcedor comprar um relógio} personalizado.

Fonte: Pesquisa de campo (2019).

- Microondas da marca X em parceria com o Flamengo

O mesmo aconteceu com o microondas com o escudo do Flamengo. A sua pontuação foi de 306 . Com isso, sua média foi 2,76 , o que significa que $27,6 \%$ das pessoas comprariam esse produto. No caso do microondas, a porcentagem é ainda menor, chegando perto de um quarto dos participantes. Outro dado importante é a rejeição desse objeto: aproximadamente 53\% dos participantes optaram por responder que não comprariam (nenhuma chance de comprar e insignificante probabilidade de que compre), o que corresponde a mais da metade do total.

Existem inúmeras marcas e modelos, porém, após uma pesquisa na internet, foi encontrado como média um valor de $R \$ 400,00$. Esse modelo que foi colocado no questionário é ficticio. Ele foi confeccionado com base em um modelo conhecido e conceituado no meio, de uma marca também respeitada com o objetivo de coletar informações para uma possível parceria com a marca do Flamengo.

Através desses resultados, vemos que não foi muito aceito pelo público. Como contrapeso, está a idade média dos participantes, que é de 26,4 anos. Nessa idade, não é nem uma preocupação e nem um interesse a compra de 
objetos como eletrodomésticos, o que pode ter influenciado nas respostas obtidas.

Qual a probabilidade de você comprar esse microondas em parceria com o Flamengo?

111 respostas

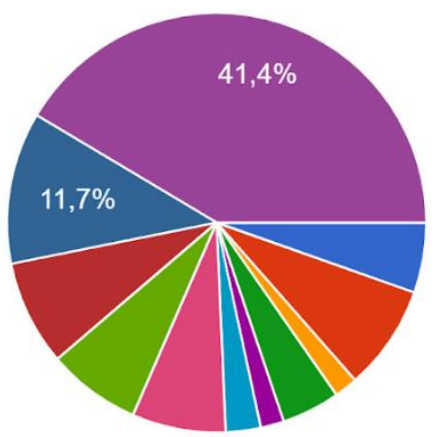

Com certeza compraria

Quase com certeza compraria

Muito provável que compre

Provável que compre

Boa probabilidade de que compre

Razoável probabilidade de que com..

Alguma probabilidade de que compre

Pouca probabilidade de que compre

$1 / 2 \nabla$

\section{Gráfico 10: Qual a probabilidade do torcedor comprar um microondas} personalizado.

Fonte: Pesquisa de campo (2019).

*OBS: Os percentuais não aparecem devido ao pequeno espaço no campo de cada opção. Segue a lista com os dados certos: Quase com certeza compraria= $8,1 \%$; Muito provável que compre $=1,8 \%$; Provável que compre $=4,5 \%$; Boa probabilidade de que compre=1,8\%; Razoável probabilidade de que compre= 2,7\%; Alguma probabilidade de que compre= 7,2\%; Pouca probabilidade de que compre $=7,2 \%$ e Pouquíssima probabilidade de que compre $=8,1 \%$.

Logo após essas quatro perguntas direcionadas a produtos do Flamengo, temos sete perguntas de forma mais geral, direcionadas para o público torcedor, com questões de conhecimento sobre fanatismo, produtos oficiais e licenciados e sobre questões envolvendo as parcerias e os clubes.

A primeira pergunta é sobre a frequência que os participantes assistem aos jogos dos seus times. A grande maioria respondeu que concorda plenamente, ou seja, que de fato assiste aos jogos dos seus times: 64,9\%. O que chama bastante atenção é que se consideramos como "concordo em parte" uma parcela do total, juntando as duas, a porcentagem de participantes que assistem os jogos do seu time, seja plenamente ou em partes, cresce para $86,5 \%$. 
Assisto a todos os jogos do meu time.

111 respostas

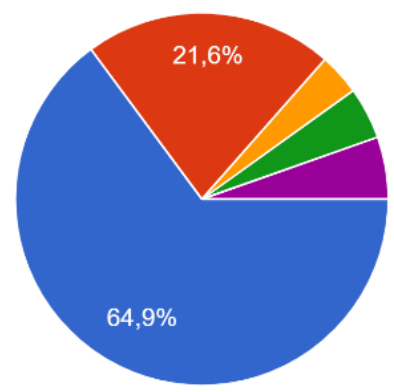

Concordo plenamente

Concordo em parte

Nem concordo, nem discordo

Discordo em parte

Discordo plenamente

Gráfico 11: Qual a frequência que o participante assiste a jogos do seu time.

Fonte: Pesquisa de campo (2019).

Já na segunda pergunta dessa etapa, o participante respondeu se possui produtos com o escudo do seu time de coração. Novamente a maioria foi esmagadora. A porcentagem que votou que sim, possui produtos com escudos do seu time foi de $71,2 \%$. Incluindo a porcentagem das pessoas que votaram que "concordam em parte", a porcentagem sobe para $88,3 \%$, ou seja, a grande maioria dos participantes possuem pelo menos um produto com o escudo do time que torcem.

Tenho produtos com o escudo do meu time.

111 respostas

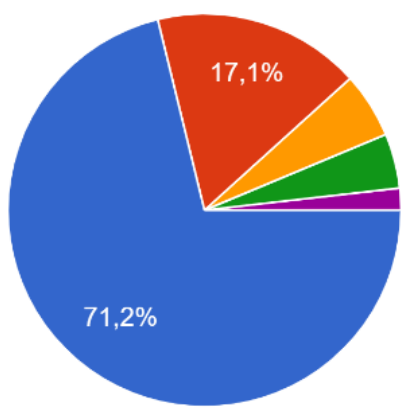

Concordo plenamente

Concordo em parte

Nem concordo, nem discordo

Discordo em parte

Discordo plenamente

Gráfico 12: Quem possui produtos com o escuto dos seus times.

Fonte: Pesquisa de campo (2019). 
Essas altas porcentagens nos levam a acreditar que o público que respondeu é algo fanático, porque além de ver os jogos do seu time, também possui produtos com o escudo do clube.

Porém, existem produtos que não são verdadeiros (mas sim pirateados) e é exatamente o tema da terceira pergunta. Nessa, as respostas começam a ficar mais divididas: $40 \%$ das pessoas responderam que os produtos que possuem, são verdadeiros; $23,4 \%$ responderam que concordam em parte com a originalidade dos produtos; 9\% não concordam e nem discordam; 12,6\% discordam em parte; 15,3\% discordam plenamente. Ou seja, a porcentagem de pessoas que concordam é de $63 \%$, ainda sendo maioria. $27,9 \%$, mais de um quarto do total, respondeu que discordam, ou seja, que compram ou ganharam produtos falsificados.

Todos os produtos que tenho que mostram o escudo do meu time são originais.

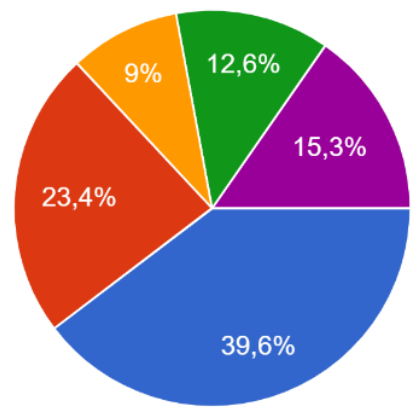

Concordo plenamente

Concordo em parte

Nem concordo, nem discordo

Discordo em parte

Discordo plenamente

\section{Gráfico 13: Originalidade dos produtos que os torcedores possuem.}

Fonte: Pesquisa de campo (2019).

$\mathrm{Na}$ quarta pergunta, o participante era questionado a respeito da perceria que acontece entre a marca do produto e o clube em questão, se era uma parceria honesta ou não. Talvez a pergunta que tenha sido mais dividida entre todas. A porcentagem de pessoas que responderam "concordo plenamente" que a parceria seja honesta foi $19,6 \%$. Já que concordam em parte foi de $26,1 \%$. Não concordam nem discordam foi de $21,6 \%$. As que discordam em parte foi de $15,3 \%$ e as que discordam plenamente foram $17,1 \%$. 
O resultado que foi mostrado na pesquisa é o mesmo resultado do consumidor de forma geral. Não existem dados ou resultados que mostrem as quantias que foram negociadas ou então os valores acordados por ambas as partes. O que se sabe, segundo uma pesquisa da ABRAL (2018), é que o setor de produtos licenciados no esporte continua crescendo e impulsionando o mercado.

O Flamengo, após seu contrato com a marca alemã Adidas, passou a investir cada vez mais em produtos de forma geral. Um desses investimentos foi no setor de produtos licenciados, em que ambas lucram e fazem com que os números da pirataria caia cada vez mais.

Acho que quando o escudo do meu time aparece em um produto que está à venda, é devido a uma parceria honesta.

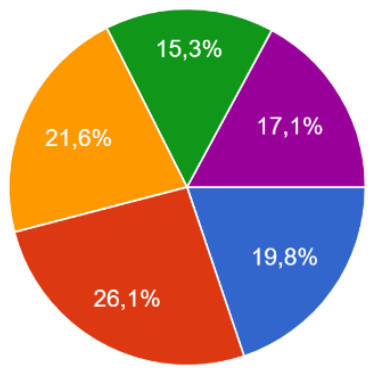

\section{Gráfico 14: Pergunta sobre o conhecimento a respeito das parcerias} que acontecem entre os clubes e as empresas que licenciam os produtos vendidos pelo Flamengo.

\section{Fonte: Pesquisa de campo (2019).}

A quinta pergunta também vai na mesma linha de raciocínio da anterior. Os participantes eram questionados a respeito das verbas que o clube recebe por ter seu escudo estampado em algum produto. 29,7\% das pessoas responderam que concordam plenamente que uma parte do valor do produto vá para o clube. $36 \%$ responderam que concordam em parte, se tornando a maioria nessa pergunta. $9 \%$ não concordam e nem discordam. 13,5\% responderam que discordam em partes. $11,7 \%$ responderam que discordam plenamente.

Essas porcentagens divergem tanto devido a um fator em comum: Pirataria. Uma pesquisa de 2017, feita pela CNDL ( Conferência Nacional de Dirigentes de Lojas ) mostrou que o valor elevado dos produtos licenciados 
influencia na hora da compra de produtos falsificados. Outro fator que pesou bastante na resposta dessa pesquisa foi o fácil acesso a produtos falsos, como por exemplo, em situações de jogos, em que o redor do estádio é todo povoado por vendedores de camisas falsas. Para ter acesso a produtos originais, o torcedor precisa entrar nas dependências do estádio, o que eventualmente é entendido como um esforço a mais.

Hoje a direção que a maioria dos times de futebol está tomando é a de justamente tornar mais fácil o acesso a esses produtos, fazendo com que o torcedor não tenha preguiça de comprar, o que resultaria em fomentar ainda mais o mercado da pirataria.

Acho que os produtos que apresentam o escudo do meu time, quando são vendidos,uma parte da receita vai para o clube.
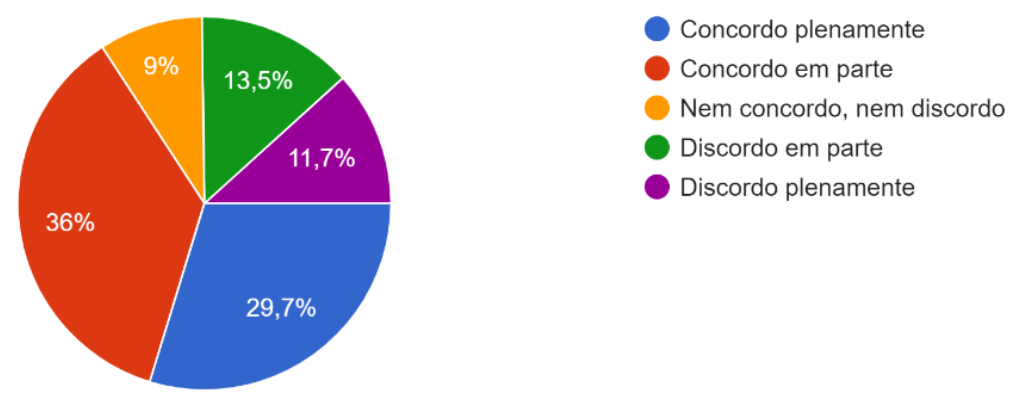

Gráfico 15: Pergunta sobre a receita que é destinada ao clube com a venda dos produtos licenciados.

\section{Fonte: Pesquisa de campo (2019).}

Porém, um grande problema que é observado é a respeito do pensamento do consumidor. A sexta pergunta trata de comprar um produto não oficial ou falso, mesmo sabendo que não estaria ajudando o time. Infelizmente, a porcentagem de pessoas que respondeu concordo plenamente foi de $27 \%$. A que respondeu concordo em parte foi $16,2 \%$. As que não concordaram e nem discordaram foi $15,3 \%$. Já as que discordaram em parte foi de $16,2 \%$. Por fim, as que discordaram plenamente de comprar produtos falsos foi de $25,2 \%$.

Mesmo sabendo que não ajudará o seu clube, a porcentagem das pessoas que comprariam produtos não oficiais foi de $43,2 \%$. Já as que não comprariam foi de $41,2 \%$. Ou seja, a porcentagem de pessoas que comprariam 
produtos falsos, ajudando a pirataria e sabendo que não estão ajudando seu time foi superior à das pessoas que não fariam isso.

Além desse dado, outras respostas anteriores, como por exemplo a da terceira pergunta, na qual mais de $25 \%$ dos participantes possuem produtos falsos, ainda ajudavam a direcionar o perfil do torcedor para um perfil que não se importa com o seu time, que não procura ajudar e que não está disposto a pagar um pouco mais para gerar um retorno para a instituição.

Eu compraria um produto não oficial do clube pelo qual torço, mesmo sabendo que não estaria ajudando o meu time.

111 respostas

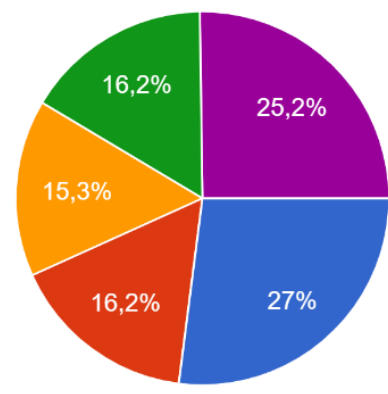

Gráfico 16: Pergunta sobre a honestidade do torcedor: se ele compraria ou não produtos não oficiais mesmo sabendo que não estariam ajudando o seu time.

Fonte: Pesquisa de campo (2019).

A última pergunta foi sobre o grau de fanatismo do torcedor. Ainda indo contra as últimas respostas, $56,8 \%$ dos participantes responderam que se consideram muito fanáticos. 18,9\% que gostam do time. 15,3\% não são muito fanáticos, mas também não deixavam de acompanhar seus times. Restando $9 \%$ para ser divididos em "pouco fanático" e "não vejo futebol".

O fato de ser muito fanático pelo time e pelo esporte deveria ir contra a resposta obtida na penúltima pergunta, fato que não aconteceu. 
Como você se define, como torcedor, em relação ao fanatismo pelo seu time de futebol?

111 respostas

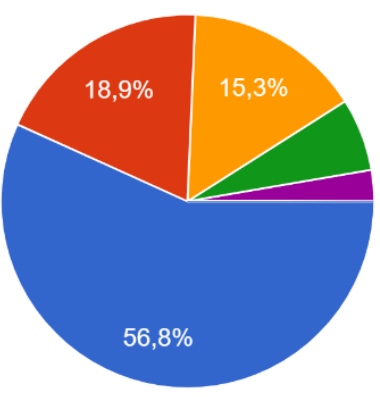

Muito fanático

Gosto do meu time

Não sou muito fanático, mas também não deixo de acompanhar

Pouco fanático

Nem vejo futebol

Gráfico 17: Qual é o grau de fanatismo do torcedor que respondeu o questionário.

Fonte: Pesquisa de campo (2019). 


\section{Conclusão}

Após analisar os dados, este estudo conseguiu concluir que o fanatismo, apenas, não é responsável pelo maior motivo de compra de produtos licenciados. Mais da metade dos participantes se disse fanático, porém mais de $40 \%$ compram produtos não oficiais, mesmo sabendo que não estariam ajudando seu time.

No caso dos exemplos dos produtos licenciados, utilizando a escada de Juster, pode-se verificar que os produtos de conveniência têm uma facilidade maior de compra e de acesso: mais de 50\% comprariam a caneca de chopp e mais de $60 \%$ comprariam a cerveja. Já no caso dos produtos de compra comparada um pouco mais de $40 \%$ das pessoas comprariam o relógio e mais de $20 \%$ comprariam o microondas, uma aceitação bem menor. Outro fator influente nos resultados pode ter sido que a grande maioria da amostra foi masculina, solteira, com a média de idade de 26,4 anos, cursando o ensino superior e com um rendimento familiar superior a de $\mathrm{R} \$ 23.345,11$.

Os objetivos intermediários foram alcançados. Analisamos a influência de fanatismo dos participantes e seus níveis de influência nas compras. O limite do torcedor relacionado aos produtos também foi alcançado: varia de acordo com o valor do produto. O microondas que é o mais caro não obteve nem a metade da aceitação da caneca, devido a questão do preço. E por fim, os produtos de conveniência e de compra comparada que foram utilizados foram selecionados por meio de praticidade/necessidade.

Além dos objetivos alcançados, os participantes entenderam exatamente como era o questionário, respondendo com clareza e certeza as questões que foram introduzidas.

Como implicações para os times, esta pesquisa serviu para mostrar que existe um potencial de crescimento nesse mercado de produtos licenciados, ainda mais se as campanhas contra pirataria forem efetivas e um sucesso. Dessa forma, além do clube deixar de perder dinheiro com esses produtos falsos, os times investindo mais nos produtos licenciados, aumentariam seus lucros e consequentemente teriam mais dinheiro para investir em mais produtos, aumentando a carta de opções e satisfazendo cada vez mais o seu cliente, que 
deixaria de procurar por produtos falsos e isso manteria uma fidelização desse cliente., gerando um ciclo sem fim.

Outra implicação para os times de futebol é olhar para seus torcedores mais fanáticos e de alguma forma dar mais valor à eles, pois a grande parcela de lucro dos produtos do seu time se dá devido a estes torcedores. 


\section{Referências Bibliográficas}

NOGUEIRA, Claudio. Zeros à direita: marketing \& mídia no esporte. Rio de Janeiro: iVentura, 2010.

REIN, Irving; KOTLER, Philip; SHIELDS, Ben. Marketing Esportivo: a reinvenção do esporte na busca de torcedores. Porto Alegre, 2008.

KOTLER, Philip; KELLER, Kevin Lane. Administração de marketing. Tradução de Sônia Midori Yamamoto, 14.ed. São Paulo: Pearson Education do Brasil, 2012.

KOTLER, Philip ; KELLER, Kevin Lane. Administração de marketing. 12 ed. São Paulo: Pearson Prentice Hall, 2006.

KOTLER, P. Marketing para o século XXI: como criar, conquistar e dominar o mercado. São Paulo: Ediouro, 2009.

MULLIN Bernard; HARDY Stephen; SUTTON William. Marketing Esportivo. 1996

GIL, Antonio Carlos. Como elaborar projetos de pesquisa. 5. ed. São Paulo: Atlas, 2008.

SOLOMON, Michael R., O comportamento do Consumidor - Comprando, possuindo e sendo. Tradução de Lene Belon Ribeiro, 7 ed. Porto Alegre. Bookman, 2008.

MELO NETO, F. P. Marketing esportivo. O esporte como ferramenta do marketing moderno. Rio de Janeiro: BestSeller, 2013.

AFIF, Antonio. A Bola da vez: o marketing esportivo como estratégia de sucesso. São Paulo: Infinito. 2000

CHURCHILL, Gilbert A. Jr; PETER, J. Paul. Marketing: criando valor para os clientes. Tradução de Cecília C. Bartalotti. 3.ed. São Paulo: Saraiva, 2012.

PESTANA, João Victor. Futebol e Consumo: O que mais motiva os torcedores dos grandes clubes cariocas a consumir. Disponível em $<$ https://www. maxwell.vrac. puc-rio.br/32708/32708.PDF>. Acesso em 27 nov. 2018. 
VIDAL, Douglas. MARKETING ESPORTIVO: O 5P DA PAIXÃO. Disponível em $<$ https://www.implantandomarketing.com/marketing-esportivo-5p-paixao/>. Acesso em 03 dez. 2018.

TERRA, Thiago. Motivação que acaba em consumo. Disponivel em $<$ https://www.mundodomarketing.com.br/reportagens/comportamento-doconsumidor/2477/-u-especial-comportamento-e-consumo-/u--br-motivacao-queacaba-em-consumo.html> Acesso em 01 dez. 2018.

CAPELO, Rodrigo. O brasileiro é mesmo tão apaixonado pelo time de futebol que torce?. ÉPOCA, 31 out. 2016. Disponível em $<$ https://epoca.globo.com/vida/esporte/noticia/2016/09/o-brasileiro-e-mesmo-taoapaixonado-pelo-time-de-futebol-que-torce.html>. Acesso em: 30 nov. 2018.

BASEGGIO, Marcelo. Grêmio e São Paulo lideram receitas com

licenciamento de marca no Brasil. GAZETA ESPORTIVA. 27 out. 2017. Disponível em $<$ https://www.gazetaesportiva.com/bastidores/gremio-e-sao-paulo-lideramranking-de-licenciamento-de-marca-no-brasil/>. Acesso em 01 nov. 2018.

SANTOS, Carlos José Giudice. TIPOS DE PESQUISA. OFICINA DA PESQUISA. fev.

2015. http://www.oficinadapesquisa.com.br/APOSTILAS/METODOL/ OF.TIPOS PESQ UISA.PDF. Acesso em 11 mai. 2019.

\section{DIRETORIA DE ESTATÍSTICAS EDUCACIONAIS DEED. RESUMO TÉCNICO CENSO DA EDUCAÇÃO SUPERIOR 2016. \\ http://download.inep.gov.br/educacao superior/censo superior/resumo tecnico/r esumo tecnico censo da educacao superior 2016.pdf. Acesso em 22 mai. 2019.}

PORTAL DO FRANCHISING. Licenciamento de produtos no setor esportivo impulsiona mercado e atrai torcedores apaixonados, , 27 set. 2017.

Disponível em <https://www.portaldofranchising.com.br/noticias/licenciamentode-produtos-setor-esportivo/>. Acesso em 27 nov. 2018. 